\title{
The Information Technology Challenge in Teaching Senior High School Geography in Ghana
}

\author{
Samuel Antwi \\ Ohio University
}

\author{
Abednego Kofi Bansah \\ University of Cape Coast
}

Teresa Franklin

Ohio University

\begin{abstract}
The use of information technologies in the field of geography, an important discipline in social sciences, contributes to rendering abstract phenomena and concepts concrete, thereby increasing high school education students' interest in geographic education. This study evaluated the extent to which information technologies has been diffused in high school geography lessons in a metropolitan area in Ghana, by focusing on geography teachers use of information technologies in teaching. In all, 40 geography teachers from 15 selected senior high schools in the metropolis were used for the study. Numerical analysis and descriptive analysis techniques were used in the analysis of the research data. Results indicated that the use of information technologies in teaching geography lessons in senior high schools was limited. The geography teachers attributed the inadequate use of information technologies to insufficient equipment, insufficient skills on the part of teachers, and inaccessibility to the available equipment. The research further indicated that teachers did not receive adequate training in the use of information technologies in their teacher preparation institutions and therefore, lacked the needed skills and were reluctant to use technology in the classroom to enhance teaching and learning.
\end{abstract}

Keywords: Teaching; Teacher Training; Technology; Technology Support; Geography

\section{Introduction}

The integration of technology into teaching and learning has become part of most educational curricula (Ali, Haolader, \& Muhammad, 2013; Buabeng-Andoh, 2013; Lai, 2015). The integration of technology for better teaching and learning outcomes have been reported in mathematics (Cheung, \& Slavin, 2013; Roschelle, J. et al. 2010), sciences (Treleas, 2016; Norrby, Grebner, Eriksson, Bostrom, 2015) and social sciences (Lai, Zhu, \& Williams, 2017; Martin, 2011). However, while such curricular aspects have aligned with some developed countries' educational systems, little can be said about some developing countries' educational systems, which are still at their early stages when it comes to integration of technology into teaching and learning for better outcomes.

While using technology for teaching any subject is important, employing it in subjects that require visual aids for learners' understanding of a subject matter cannot be overstated. Research indicates that $83 \%$ of what is learnt is from the sense of sight, and people 
generally remember $70 \%$ of what they say and $90 \%$ of what they see as they undertake an activity (Cuban, 2001, cited in Shabiralyani, Hassan, Hamad, \& Iqbal, 2015). One subject that requires visual aids for learners' discovery and navigation is geography.

The abstract nature of geographical concepts such as longitudes and latitudes suggests a need for the support of visual materials to facilitate learning. According to Earle (2002), an important part of geography in secondary education consists of abstract knowledge, and therefore it is crucial for teachers to use appropriate information technologies to convey geographical information to students. Also, Sawyer, Buthler and Curtis (2010) are of the view that instructors can take the opportunity, with the aid of the internet and webcam, to illustrate a variety of geographic examples and exercises for learners. The assertion by these authors reiterates the vital role technology can play when teaching geography lessons. However, with reportedly limited ICT infrastructure (Agyei, 2014; Agyei \& Voogt, 2011), the absence of widespread usage of ICT in education (Agyei, 2014), and an average of 30 students to a computer at the senior high school level (Mereku, Yidana, Hordzi, Tete-Mensah, Tete-Mensah, \& Williams, 2009), integrating technology into teaching and learning remains a daunting task in Ghana. These stated infrastructural challenges call into question teachers' knowledge and ability to integrate technology into teaching and learning of subjects like geography, which requires visual/media aids for learners understanding. The purpose of this study was to examine the use of information technologies in the teaching and learning of geography in Ghanaian senior high schools, and to expose the challenges, and possible solutions, therein.

\section{Literature Review}

There is paucity of data when it comes to the usage of technology to enhance teaching and learning of geography in Ghana, hence the limited current literature associated with the application of technology for teaching Geography. Teaching and learning with technology has become one of the major characteristics of the twenty-first century classroom. In an ideal world, all students would have access to technologies available whenever they want to use them.

The current opportunity for achieving sustainable educational reform is enhanced by an emerging understanding about how education is delivered and the advent of powerful educational technologies (Agyei, 2014). Technology in various forms has transformed decision-making in government, society, academia, and industry. Some educators consider technology to be one of the most promising means for implementing educational reforms (Mikre, 2011). However, the use of technology in teaching and learning of geography has been adopted by only a small percentage of senior high schools in Ghana (Acquah, Asamoah, \& Konadu, 2017; Mfum-Mensah, 2003).

According to Mfum-Mensah (2003), the developing world perceives Information Communication and Technology (ICT) as a tool that will promote socioeconomic, political, and sustainable development. The education policymakers in Ghana have embraced the use of information technologies in teaching high school students (Curriculum Research 
and Development Division, 2007; Ministry of Education, 1999a). This perception has led to the introduction of computers and the Internet into some senior high schools in Ghana, and this has contributed to knowledge production and information sharing among students and teachers in the school system. It is reported that information technology is a transformative tool, and its full integration into the school system is necessary to prepare students for the information society which they will inherit (Davidsen \& Christiansen, 2014; Davidsen, \& Georgsen, 2010; Hakkarainen, Ilomaki, Lipponen, Muukkonen \& Rahikainen, 2000)

The inequality of educational materials and resources, including the use of computers and other information technologies in schools is one of the major educational problems in Ghana (Buabeng-Andoh, \& Yidana 2015; Dankwa, 1997). Dankwa (1997) revealed that in Ghana, "information technologies provisions to secondary schools are skewed in favor of schools categorized as premier schools and schools in urban areas" (p. 4). Since the introduction of formal schooling in Ghana, educational resources have been unequally distributed in the school system (Folson, 1995; Inkoom, 2009; Natia \& Al-hassan, 2015). Mfum-Mensah (2003) cautioned that educational policy makers in Ghana should ensure that information technology does not become another tool for perpetuating educational inequalities in Ghana's school system.

The potential of using information technologies in the classroom has prompted the United States, Britain, and other developed nations to implement a Geographic Information Systems (GIS) into some elementary, middle, and high school curricula (Audet \& Paris, 1997; Kerski, 2001; Patterson, Reeve \& Page, 2003). Geographic Information Systems (GIS) is a multidisciplinary technological tool which combines various stand-alone technologies into a most powerful decision tool (Shin, 2006). The potential of GIS not only lies with the study of geography as a subject but extends to tourism management (Wei. 2012) and plays a pivotal role in the medical field (Brooker \& Michael, 2000; World Health Organization, 2007). Having a hands-on knowledge of the application extends beyond classroom activities as GIS applications extends beyond mapping (National Geographic Society, 2016) to disaster management and mitigation (Cova, 1999), landslide hazard zonation (Vedat, 2017), environmental impact analysis (Warner\& Diab, 2012), urban planning (Murayama, \& Thapa, 2008), and telecom and network services (Fry, 1999), just to mention a few. With the aforementioned uses of the GIS, students' ability to use it or understand its versatility could go a long way to open future avenues for them, be it furthering their education or their career opportunities. Typically, a professional GIS package is an integration of components designed to create, store, retrieve, manipulate, and display various types of geographic information. A special feature of GIS that fascinates educators is its ability to swiftly and dynamically represent the world and its issues from a variety of spatial perspectives (Baker, 2015; Bednarz, 2004; Brownell, 1997; Kerski, 2001). Students not only learn by hearing and seeing. They also have the ability and opportunity to personally apply the knowledge using higher-order skills such as problem solving and synthesis (Brownell, 1997; Jarvis, Kraftl, \& Dickie, 2017; Shin, 2006). 
Hands-on activities could include matching the positions of diverse geographical outlines or to determine how they relate to each other. A typical example is using available information to discover the fastest driving path between two points. The same map could include sites that produce pollution, such as gas stations, and sites that are sensitive to pollution, such as wetlands. Such a map would help people determine which wetlands are most at risk (National Geography Society [NGS], 2016).

The recent need for technological advancement to aid Ghana in its goal to become one of the middle-income countries in Sub-Saharan Africa prompted the researchers to seek to determine the extent to which senior high school students are exposed to information technologies in teaching and learning of geographic concepts, and to explain the current state of information technologies in geography education. As products of the Ghanaian educational system, students are expected to help in the development of the country, and as such, being vested in some geographical technology software cannot be overstated. A software program like GIS plays a pivotal role in a country's development when it comes to telecom and network services, urban planning, transportation planning, and flood damage estimation, to mention a few. The current study sought to determine the use of information technologies and how to improve them to assist student learning and teachers' efforts to teach geographic content and skills. The following research questions guided the study:

1. To what extent are information technologies being used in the teaching and learning of geography in Ghanaian senior high schools in the Ashanti Region?

2. What are the challenges of using information technologies in teaching high school geography?

3. What are the participants' current views regarding how information technologies could be effective in the teaching and learning of geography at the high school level?

\section{Methods}

\section{Study Design and Sample}

Prior to the collection of data, this study was approved by the Institutional Review Board at Minot State University, Minot, North Dakota. The study was conducted in a metropolitan area in a southern part of Ghana with a population of about 1,730,249 people (Ghana Statistical Service, 2014. As at the time of data collection the area has 30 senior high schools and 75 geography teachers (Ministry of Education, 2015).

The participants in this study were senior high school geography teachers. In all, 15 Senior high schools in the metropolis were randomly selected for the study. These schools were selected for the study because of their access to modern technology. There was a total of 40 geography teachers in the 15 schools, and all participated in 
the study. The participants were qualified teachers possessing at least a bachelor's diploma in education and at most a master's degree. Participants had diverse teaching experiences, ranging from one year to fifteen years.

The data collection method used was a survey in which literature concerning the use of information technologies for teaching and learning provided a foundation for the questions. The 40 participants were asked to respond to 17 survey questions designed for the study. At least two geography teachers were selected from each school to respond to the survey questions. All of the 40 geography teachers selected for the study responded to the survey questions. The response rate to the survey questions was $100 \%$.

To ensure confidentiality, each set of survey questions were mailed along with a selfaddressed return envelope. Respondents were given special identification numbers for analysis purposes. Also, for confidentiality, all the 15 high schools selected for the study were given special identification numbers for analysis. Descriptive analysis techniques were used in the data analysis. Similar expressions were determined and transferred to tables representing numerical data such that frequencies in quantitative analysis form could be identified. In order to achieve validity in the study, direct quotations were used in descriptive analysis to reflect the extent to which information technologies are being used in these schools to enhance teaching and learning of geographic concepts.

\section{Results}

Of the 15 schools, 5 (33.3\%) had student population above 2001. The remaining demographical information for selected schools are provided in Table 1. A majority of the respondents $(n=16,40 \%)$ had taught between one to five years (Table 2). Of the 40 respondents $31(77.5 \%)$ had Bachelor of Education degree and $5(12.5 \%)$ had attained a Master of Education degree (Table 2). None (0\%) of the respondents affirmed the presence of a geography resource center (Table 2). The majority of the geography teachers $(n=30$, $75 \%$ ) indicated that they had a science resource room, but it was rarely used in teaching geography lessons. Some teachers $(n=33,82.5 \%)$ mentioned that while the government had built science resource centers in some selected schools, these were shared with other schools in the school district. Moreover, these centers were usually used to teach physical sciences and not geography lessons.

Table 1.

Demographical information of the selected schools

\begin{tabular}{ccccc}
\hline $\begin{array}{c}\text { Name of } \\
\text { School }\end{array}$ & Student Population Geography Majors & $\begin{array}{c}\text { Geography } \\
\text { Teachers }\end{array}$ & IT ${ }^{1}$ Teachers \\
\hline A & above 2001 & above 251 & $4-7$ & $4-7$ \\
B & above 2001 & above 251 & $4-7$ & $4-7$ \\
C & above 2001 & above 251 & $1-3$ & $4-7$ \\
\hline
\end{tabular}

(Continued) 
Table 1.

Demographical information of the selected schools (continued).

\begin{tabular}{ccccc}
\hline $\begin{array}{c}\text { Name of } \\
\text { School }\end{array}$ & $\begin{array}{c}\text { Student } \\
\text { Population }\end{array}$ & $\begin{array}{c}\text { Geography } \\
\text { Majors }\end{array}$ & $\begin{array}{c}\text { Geography } \\
\text { Teachers }\end{array}$ & IT'Teachers \\
\hline D & above 2001 & above 251 & $1-3$ & $4-7$ \\
E & above 2001 & above 251 & $1-3$ & $4-7$ \\
F & $1501-2000$ & $201-250$ & $1-3$ & $4-7$ \\
G & $1501-2000$ & $201-250$ & $1-3$ & $1-3$ \\
H & $1501-2000$ & $201-250$ & $1-3$ & $1-3$ \\
I & $1501-2000$ & $151-200$ & $1-3$ & $1-3$ \\
J & $1501-2000$ & $151-200$ & $1-3$ & $1-3$ \\
K & $1501-2000$ & $151-200$ & $1-3$ & $1-3$ \\
L & $1501-2000$ & $101-150$ & $1-3$ & $1-3$ \\
M & $1001-1500$ & $101-150$ & $1-3$ & $1-3$ \\
N & $500-1000$ & $50-100$ & $1-3$ & $1-3$ \\
O & $500-1000$ & $50-100$ & $1-3$ & $1-3$ \\
\hline
\end{tabular}

${ }^{1}=$ Information Technology

Table 2.

Demographical information of the selected teachers and frequency of IT support received.

\section{Frequency (f) Percentage (\%)}

No. of years taught

Currently in the 1st year

17.5

$1-5$

7
$16 \quad 40.0$

$6-10$

10

25.0

$11-15$

4

Above 16 years

3

10.0

\section{Level of Education}

$\begin{array}{ccc}\text { Master of Education } & 5 & 12.5 \\ \text { Bachelor of Education } & 31 & 77.5 \\ \text { Diploma in Education } & 1 & 2.5 \\ \text { Bachelor of Art } & 3 & 7.5\end{array}$


Table 2.

Demographical information of the selected teachers and frequency of IT support received (continued).

\begin{tabular}{llcc}
\hline & & Frequency (f) & Percentage (\%) \\
\hline $\begin{array}{l}\text { Presence of Geography } \\
\text { Resource Centre }\end{array}$ & & & \\
& Yes & 40 & 0.0 \\
& No & & 100.0 \\
\hline Presence IT Resource & & & \\
Centre & Yes & 40 & 100 \\
& No & 0 & 0 \\
\hline Received Help from IT & & & \\
Instructors & & 0 & 0.0 \\
& Very frequently & 0 & 0.0 \\
& Frequently & 8 & 20.0 \\
& Occasionally & 12 & 30.0 \\
& Rarely & 20 & 50.0 \\
\hline
\end{tabular}

As a result, the teachers seldom had access to some of the IT facilities they might need in teaching geography lessons. All (100\%) of the respondents affirmed they had an Information Technology Department (ITD) in their schools. This question was asked to elicit from the participants if they had a separate ITD that was used in teaching geography lessons that involved the use of information technologies. Participants reported that the benefits geography teachers received from the ITD in teaching geography lessons that involved the use of information technologies were very limited. With regard to geography teachers receiving help from IT in teaching geography lessons that involved the use of information technologies, 20 (50\%) teachers indicated that they had never received any help from IT instructors in teaching their geography lessons (Table 2). Respondents reported that while computing/IT are taught separately, rarely are they integrated into other subjects such as geography.

Nineteen of the 40 of the teachers ranked insufficient access to technology as the major problem they face in their schools (Table 3). Participants emphasized that their schools had science resource centers with IT equipment that could be used in teaching geography lessons, but they did not have access to those facilities. Sharing the facilities was difficult for participants because the science instructors were constantly using them.

Responses to the frequency of use of some selected applications and their availability indicated that majority of geography teachers reported never using the listed applications 
(Table 4). Even though geography students are required to take map interpretation as part of their external examinations, only 10 (25\%) participants from five schools said they used Infomaps monthly or even once a term in teaching geography lessons. Infomaps is used to enhance students' understanding map interpretations. Furthermore, none of the geography teachers had ever used ArcView, a software package that is very useful in teaching geographical concepts.

Table 3.

Ranking challenges of using information technologies in teaching.

\begin{tabular}{|c|c|c|c|c|c|c|}
\hline \multirow[b]{2}{*}{ Challenges } & \multicolumn{6}{|c|}{ Ranking $^{1}$} \\
\hline & 1 & 2 & 3 & 4 & 5 & 6 \\
\hline Insufficient skills on the part of the teachers & 13 & 17 & 2 & 3 & 3 & 2 \\
\hline Lack of software for use on available computers & 4 & 5 & 19 & 4 & 2 & 6 \\
\hline Lack of usable data about the desired focus topic & 5 & 7 & 3 & 2 & 1 & 21 \\
\hline Insufficient access to technology & 19 & 9 & 4 & 3 & 2 & 3 \\
\hline $\begin{array}{l}\text { Inadequate time allocated on timetable for teaching } \\
\text { geography and IT }\end{array}$ & 9 & 4 & 2 & 18 & 2 & 4 \\
\hline $\begin{array}{l}\text { Lack of specific relevant curriculum that includes } \\
\text { the use of information technology }\end{array}$ & 5 & 2 & 2 & 2 & 20 & 8 \\
\hline
\end{tabular}

Participants further reported that information technology facilities such as projectors, slides, and computers were available in their schools, but they had no access to them for teaching geography lessons.

Responses for how often teachers required their students to use information technologies to perform some selected IT tasks/activities for geography lessons are summarized in Table 5.

Table 4.

How frequently selected IT applications were used with students.

\begin{tabular}{|c|c|c|c|c|c|c|}
\hline IT Applications & Daily & Weekly & Monthly & $\begin{array}{c}\text { Once } \\
\text { or Twice } \\
\text { a Term }\end{array}$ & Never & $\begin{array}{c}\text { Not } \\
\text { Available }\end{array}$ \\
\hline Computers in General & 2 & 1 & 4 & 8 & 20 & 5 \\
\hline Word Processing Packages & 2 & 2 & 5 & 2 & 21 & 8 \\
\hline ArcView & 0 & 0 & 0 & 0 & 22 & 18 \\
\hline Graphical Applications & 2 & 3 & 3 & 8 & 16 & 8 \\
\hline $\begin{array}{l}\text { Presentation Software (eg., } \\
\text { PowerPoint) }\end{array}$ & 0 & 2 & 1 & 4 & 24 & 9 \\
\hline
\end{tabular}

(Continued) 
Table 4.

How frequently selected IT applications were used with students (continued).

\begin{tabular}{|c|c|c|c|c|c|c|}
\hline IT Applications & Daily & Weekly & Monthly & $\begin{array}{l}\text { Once } \\
\text { or Twice } \\
\text { a Term }\end{array}$ & Never & $\begin{array}{c}\text { Not } \\
\text { Available }\end{array}$ \\
\hline Infomaps & 0 & 4 & 12 & 10 & 8 & 6 \\
\hline $\begin{array}{l}\text { Interactive Whiteboard (e.g. } \\
\text { Smartboard) }\end{array}$ & 0 & 0 & 0 & 4 & 6 & 30 \\
\hline $\begin{array}{l}\text { Search Engines for Internet } \\
\text { (e.g Infoseek, Yahoo, } \\
\text { Google Earth) }\end{array}$ & 0 & 3 & 6 & 3 & 24 & 7 \\
\hline Interactive CDs & 0 & 2 & 1 & 6 & 22 & 9 \\
\hline Slides & 0 & 0 & 0 & 4 & 28 & 8 \\
\hline Overhead Projector & 0 & 0 & 2 & 3 & 20 & 15 \\
\hline Television & 1 & 1 & 3 & 5 & 22 & 9 \\
\hline Simulation Programs & 0 & 0 & 2 & 5 & 23 & 10 \\
\hline Radio & 0 & 1 & 3 & 5 & 25 & 7 \\
\hline Fluffy Maps & 0 & 0 & 1 & 3 & 15 & 21 \\
\hline Educational Portals & 0 & 0 & 0 & 0 & 10 & 30 \\
\hline $\begin{array}{l}\text { Drill/Practice Programs/ } \\
\text { Tutorials }\end{array}$ & 2 & 6 & 11 & 3 & 9 & 10 \\
\hline
\end{tabular}

Note. Totals do not equal number of respondents. A participant could mark more than one.

Responses on comfort levels in using some selected information technologies in teaching geography lessons indicated that $22(55 \%)$ and $16(40 \%)$ participants were comfortable in using Infomaps and computers in general, respectively (Table 6). Table 6 provides additional information on the comfort levels of participants in using technology. Participants expressed the lack of internet availability, which prevented student access to data. Internet availability could support students' clear understanding of how some land features are formed and where these are located on the globe.

Table 5.

How often geography teachers required students to perform selected IT tasks.

\begin{tabular}{lccccc}
\hline IT Task/activity & Daily & Weekly & Monthly & $\begin{array}{c}\text { Once or } \\
\text { Twice a Term }\end{array}$ & Never \\
\hline $\begin{array}{l}\text { To organize and store information } \\
\begin{array}{l}\text { To collect data and perform } \\
\text { measurements }\end{array}\end{array}$ & 1 & 2 & 4 & 7 & 26 \\
\hline
\end{tabular}


Table 5.

How often geography teachers required students to perform selected IT tasks (continued).

\begin{tabular}{|c|c|c|c|c|c|}
\hline IT Task/activity & Daily & Weekly & Monthly & $\begin{array}{c}\text { Once or } \\
\text { Twice a Term }\end{array}$ & Never \\
\hline $\begin{array}{l}\text { To manipulate/analyze/ interpret } \\
\text { data }\end{array}$ & 2 & 3 & 5 & 9 & 21 \\
\hline $\begin{array}{l}\text { To create visual displays of data/ } \\
\text { information (e.g. graphs, charts, } \\
\text { maps) }\end{array}$ & 1 & 1 & 6 & 8 & 24 \\
\hline $\begin{array}{l}\text { To plan, draft, proofread, revise, } \\
\text { and publish written text. }\end{array}$ & 0 & 1 & 2 & 7 & 30 \\
\hline $\begin{array}{l}\text { To create graphics or visuals of } \\
\text { non-data products (e.g. diagrams, } \\
\text { pictures, figures) }\end{array}$ & 0 & 3 & 2 & 8 & 27 \\
\hline To create visual presentation & 0 & 2 & 5 & 9 & 24 \\
\hline To perform calculations & 0 & 1 & 2 & 22 & 14 \\
\hline To create models or simulations & 0 & 0 & 2 & 5 & 33 \\
\hline To support individualized learning & 3 & 2 & 3 & 5 & 28 \\
\hline For remediation for basic skills & 1 & 1 & 6 & 8 & 24 \\
\hline $\begin{array}{l}\text { To compensate for a disability or } \\
\text { limitation }\end{array}$ & 1 & 0 & 3 & 2 & 34 \\
\hline
\end{tabular}

Table 6.

Geography teachers' comfort level in using selected information technologies.

\begin{tabular}{lcccc}
\hline IT Application & $\begin{array}{c}\text { Very } \\
\text { Comfortable }\end{array}$ & $\begin{array}{c}\text { Moderately } \\
\text { Comfortable }\end{array}$ & $\begin{array}{c}\text { Need } \\
\text { Help }\end{array}$ & $\begin{array}{c}\text { Need a lot } \\
\text { of Help }\end{array}$ \\
\hline Computers in General & 16 & 9 & 10 & 5 \\
Word Processing Packages & 10 & 8 & 7 & 15 \\
Spreadsheet & 5 & 6 & 9 & 20 \\
ArcView & 1 & 1 & 14 & 24 \\
Graphical Applications & 2 & 1 & 22 & 15 \\
Presentation Software (e.g. & 8 & 15 & 7 & 10 \\
PowerPoint) & 22 & 10 & 6 & 2 \\
Infomaps & 12 & 14 & 11 & 3 \\
$\begin{array}{l}\text { Any Internet Activity } \\
\text { Search Engines for the }\end{array}$ & 22 & 12 & 4 & 2 \\
Internet (Google) & & & & \\
\hline
\end{tabular}


Table 6.

Geography teachers' comfort level in using selected information technologies (continued).

\begin{tabular}{lcccc}
\hline IT Application & $\begin{array}{c}\text { Very } \\
\text { Comfortable }\end{array}$ & $\begin{array}{c}\text { Moderately } \\
\text { Comfortable }\end{array}$ & $\begin{array}{c}\text { Need } \\
\text { Help }\end{array}$ & $\begin{array}{c}\text { Need a lot } \\
\text { of Help }\end{array}$ \\
\hline Interactive Whiteboard (e.g. & 0 & 8 & 18 & 14 \\
Smartboard) & 2 & 3 & 21 & 14 \\
Simulation Programs & 8 & 6 & 16 & 10 \\
Interactive CDs & 7 & 9 & 20 & 4 \\
Google Earth & 6 & 12 & 16 & 6 \\
Overhead Projector & 5 & 6 & 18 & 11 \\
Slides & 28 & 3 & 7 & 2 \\
Television & 2 & 14 & 16 & 8 \\
Fluffy Maps & 2 & 9 & 21 & 7 \\
Educational Portals & 27 & 8 & 3 & 2 \\
Radio & & & & \\
\hline
\end{tabular}

With regard to participants' confidence levels in effectively using computers in general and Infomaps, 25 (62.5\%) and 23 (57.5\%) respectively responded affirmatively. Seventyfive percent of the participants indicated that even though they knew about Google Earth, they could not use it effectively. Table 7 summarizes the participants' confidence in using the selected applications effectively. Data from the results indicated that a majority of the teachers did not receive training regarding how to use the listed IT applications in enhancing teaching and learning (Table 8).

Table 7.

Geography teachers' confidence in ability to use selected information technologies.

\begin{tabular}{lccc}
\hline IT Applications & $\begin{array}{c}\text { I Know and Can } \\
\text { Use Effectively }\end{array}$ & $\begin{array}{c}\text { I Know but Cannot } \\
\text { Use Effectively }\end{array}$ & $\begin{array}{c}\text { I Do Not Know } \\
\text { What This is }\end{array}$ \\
\hline Computers in General & 25 & 15 & 0 \\
$\begin{array}{l}\text { Word Processing } \\
\text { Packages }\end{array}$ & 17 & 20 & 3 \\
Spreadsheet & 12 & 26 & 2 \\
ArcView & 0 & 26 & 14 \\
Graphical Applications & 5 & 25 & 10 \\
$\begin{array}{l}\text { Presentation Software } \\
\text { (e.g. PowerPoint) }\end{array}$ & 18 & 20 & 2 \\
Infomaps & 23 & 15 & 2 \\
\hline & & & (Continued)
\end{tabular}


Table 7.

Geography teachers' confidence in ability to use selected information technologies. (continued).

\begin{tabular}{lccc}
\hline IT Applications & $\begin{array}{c}\text { I Know and Can } \\
\text { Use Effectively }\end{array}$ & $\begin{array}{c}\text { I Know but Cannot } \\
\text { Use Effectively }\end{array}$ & $\begin{array}{c}\text { I Do Not Know } \\
\text { What This is }\end{array}$ \\
\hline $\begin{array}{l}\text { Any Internet Activity } \\
\text { Search Engines for }\end{array}$ & 21 & 16 & 3 \\
internet & 18 & 15 & 7 \\
Interactive Whiteboard & 7 & 28 & 5 \\
(E.g., Smartboard & 2 & 14 & 24 \\
Simulation Programs & 12 & 22 & 6 \\
Interactive CDs & 7 & 30 & 3 \\
GoogleEarth & 8 & 31 & 1 \\
Overhead Projector & 15 & 21 & 4 \\
Slides & 28 & 12 & 0 \\
Television & 9 & 25 & 6 \\
Fluffy Maps & 4 & 16 & 20 \\
Portals & 30 & 10 & 0 \\
Radio & & & \\
\hline
\end{tabular}

Table 8.

Participants' preparation at teacher training schools on how to use selected information technologies.

\begin{tabular}{lcc}
\hline IT Applications & $\begin{array}{c}\text { Taught at Teacher } \\
\text { Preparation }\end{array}$ & $\begin{array}{c}\text { Not Taught at Teacher } \\
\text { Preparation }\end{array}$ \\
\hline Computers in General & 10 & 30 \\
Word Processing Packages & 3 & 37 \\
Spreadsheet & 1 & 39 \\
ArcView & 0 & 40 \\
Graphical Applications & 2 & 38 \\
Presentation Software (e.g. & 3 & 37 \\
PowerPoint) & 6 & 34 \\
Infomaps & 4 & 36 \\
Any Internet Activity & 1 & 39 \\
$\begin{array}{l}\text { Search Engines for the Internet } \\
\text { (Google) }\end{array}$ & & \\
\hline
\end{tabular}


Table 8.

Participants' preparation at teacher training schools on how to use selected information technologies (continued).

\begin{tabular}{lcc}
\hline IT Applications & $\begin{array}{c}\text { Taught at Teacher } \\
\text { Preparation }\end{array}$ & $\begin{array}{c}\text { Not Taught at Teacher } \\
\text { Preparation }\end{array}$ \\
\hline $\begin{array}{l}\text { Interactive Whiteboard (e.g. } \\
\text { Smartboard) }\end{array}$ & 3 & 37 \\
Simulation Programs & 0 & 40 \\
Interactive CDs & 6 & 34 \\
Google Earth & 2 & 38 \\
Overhead Projector & 9 & 31 \\
Slide & 12 & 28 \\
Television & 4 & 36 \\
Fluffy Maps & 1 & 39 \\
Educational Portals & 1 & 39 \\
Radio & 5 & 35 \\
\hline
\end{tabular}

\section{Discussion}

The use of information technologies in education in the twenty-first century rivals the industrial revolution in the nineteenth century (Zeigler, 2007). The field knowledge of the teachers, who implement the changing curricula in classrooms and their command of the information technologies, as well as the learning-teaching process, should be supported with necessary equipment. The responses from the geography teachers in general discussions before the survey indicated that they have information technology departments and that each school had the capability of helping geography students learn with information technologies. The results obtained from the study suggest a different situation. The responses from the participants in the study revealed that they did not have access to information technology facilities needed for geography lessons and, moreover, they received limited training or no instructional help with information technology.

The results revealed that the limited number of computers in the participants' schools did not promote the use of software such as ArcView and PowerPoint, which are very efficient in teaching geographic concepts. Data suggests that because the internet accessibility was limited to only computer laboratories; the geography teachers did not often use search engines such as Google Earth, Infoseek, and/or Infomaps, in promoting geographical concepts.

Even though some senior high schools were equipped with information technologies, geography teachers were not competent to utilize these facilities in teaching and learning. 
The lack of confidence among the participants in using IT in teaching suggests the inability to deliver instructions that could elicit hands-on activities, feedback, assessment of performance, and learning; this supports Dooley's (1999) assertion that when teachers lack the necessary confidence to integrate a technology into their lessons, they tend to ignore it. Mumtaz (2002) was of the view that access to resources, quality of software and hardware, ease of use, incentives to change, support, collegiality in the school, and commitment to professional learning are among other factors influencing teachers' decisions to use new technologies in classrooms.

The results from this study suggest that due to the lack of use of IT applications during participants' training, they become reluctant to use the available facilities even if they had access, and they lack the confidence to learn the applications on their own. With proper training, teachers could make geography lessons more practical to students. In addition, with properly trained personnel, school districts and school administrators could use information technologies to efficiently handle the various non-instructional tasks (for example, facility planning and demographic information system development to support the purpose and mission of schools).

The majority (35 out of 40) of the participants were of the view that the Ministry of Education in Ghana should make a commitment to regularly organize in-service training for geography teachers on how to use information technologies in teaching geographic concepts. Fourteen $(35 \%)$ of the geography teachers stated, "even though they could not get opportunity to learn how to use some modern information technologies in classroom, they were making their own effort to learn them in order to use them effectively and efficiently in their teaching." Zhang (2007) noted that appropriate use of modern information technology is needed for modern geography instruction, the quality of education, and also of the qualified geography personnel in the twenty-first century.

A section in the geography exam requires students to interpret topographical maps, and a majority of the participants took it upon themselves to learn to use Infomaps to build students' understanding on map interpretation. Others sought external help in using software such as ArcView, spreadsheets, and graphical applications due to limited or no training at their various Teacher Training Colleges. As such, the limited training and skills on the part of the participants suggested that they are not efficient in using information technologies to enhance teaching and learning. A number of them $(n=25,62.5 \%)$ mentioned that even though they knew the majority of the information technologies, such as ArcView, Google Earth, interactive CDs, and PowerPoint, they could not use them effectively in the classroom lessons. The least known information technologies were simulation programs and educational portals.

A majority of the geography teachers were of the view that the decentralization of educational policies and decision-making should be put in place so that school districts capable of financing information technology facilities can contribute to the cause. Others suggested that agencies such as telecommunications could also contribute by providing information technology facilities and internet access for schools as part of their social 
responsibilities. Participants lamented collaboration did not exist between the Information Technology Department in the selected high schools and the other subject areas such as geography.

The incompetence of geography teachers in using IT for teaching in their subject area exposes their students' inability to use IT for reading and interpreting maps, which might affect performance in the subject. This sentiment was also shared by Amosun (2016), who asserted that a teachers' inability to exhibit confidence in IT leads to students underperforming in the subject matter. Amosun (2016) listed the following:

1. Inappropriate methods of teaching,

2. Poor teacher preparation,

3. Inadequate teaching materials,

4. Inexperienced teachers,

5. Lack of in-service training and,

6. Lack of geography room (p. 44-46).

among others to be the leading causes of difficulty in teaching map interpretations with technology.

In response to how information technology could be effective in teaching and learning, participants placed more emphasis on strengthening the supply of information technology materials as well as the provision of in-service training. This was reflected in a participants' statement:

"Geography resource rooms need to be provided for teaching geography lessons rather than relying on science laboratories, which we hardly get access to."

Another participant indicated:

"Classrooms should be furnished with some IT facilities such as computers, projectors, and Smartboards that are needed on daily basis."

Another participant further stressed:

"My school has a science resource center equipped with some facilities I need in teaching geography lesson, but because there is no collaboration between IT Department and that of geography, I do not have access to facilities I may need for geography lessons."

These concerns further buttress other works that elucidate the ineffective IT usage by teachers as a result of lack of resources (Hennessy, Harrison, \& Wamakote 2010; Kihoza, Zlotnikova, Bada, \& Kalegele, 2016; MaKinster, \& Trautmann, 2014; Rastogi, \& Malhotra, 
2013) and training (Doering, Koseoglu, Scharber, Henrickson, \& Lanegran, 2014; Goktas, Yildirim, \& Yildirim, 2009; Jo, 2016; Smith, Moyer, \& Schugar, 2011).

This research attempted to explain how the use of information technologies for the teaching of geography is occurring in Ghanaian senior high schools amid the hopes of the government building a middle-income economy by the year 2020 (Amenyo, 2003). In the process of conducting this study, it became apparent that more research is needed to investigate how students build their geographic understanding with the use of Geographic Information Systems.

Other studies on information technology implementation in Ghana have revealed that technical support is a challenge to information technology implementation (Amenyo, 2003; Mangesi, 2007; Natia, 2015; Quist, 2003). It is also noted that the major challenge for schools that have access to information technology facilities is lack of resources and proper implementation by trained personnel (Mangesi, 2007; Natia, 2015).

The use of information technologies has gained much attention in both developed and developing nations around the world. While many educational ministries around the world have made the commitment to computerize schools, few have developed coherent strategies to integrate technology fully as a pedagogical tool in the classrooms (Hawkins, 2002; Munienge, Jones, Muhandji, 2013; Patel \& Patel, 2017). In the light of this, it is recommended that future researchers examine how various subjects offered at the senior high schools benefit from the available information technology facilities to enhance teaching and learning.

According to Mfum-Mensah (2003), due to the lack of a policy framework, ICT implementation in the school system is currently uncontrollable, irrespective of government initiatives. Amenyo, (2003) cautions that any attempt to implement a well-meaning ICT project in a haphazard and context-independent manner would not help in sustaining such a project. In order to have equal distribution of information technology facilities in all senior high schools, future research is needed to investigate how information technology facilities are distributed among Ghanaian rural senior high schools and urban senior high schools. Also, more research should be conducted to investigate how geography teachers are trained at the teacher training institutions on the use of information technologies to enhance teaching and learning in all subject areas, including geography.

The role of information communication and technology in education cannot be overstated and it behooves every stakeholder within the education community to play a role. While decisions to acquire or distribute ICT resources hinge on government subventions, it would be prudent for decisions on purchases of IT resources for schools to be decentralized for school districts that are capable of financing IT facilities. As much as IT resources are vital, it is paramount for the human resources to be capable and competent enough to utilize these resources for teaching and learning of geography, hence the need to occasionally organize training or refresher courses for the usage of these IT resources and software for teaching geography. 
One of the most sought after skills for the 21 st Century is collaboration. Therefore, schools within close proximity could advocate for government/non-governmental organization/ private sector/ development partners to establish an ICT centre for teaching and learning. This could quickly facilitate the establishment of a well-furnished IT resource centre instead of all the schools within that close proximity seeking an IT Resource Centre of their own. The availability of these IT centres also has implication for curricula in terms of enough time allocation for geography lessons as well as personal participation of the students during geography lessons through well designed practical sessions. Heads of senior high schools should be encouraged to reach out to private sector organizations, nongovernmental organizations, alumni and parents through written proposals to facilitate IT resource donation for their schools instead of waiting for government subventions. Having a policy in place which would require Heads of senior high schools to have proposal writing skills or be trained in proposal writing would go a long way in promoting these schools for IT resource donations.

\section{Conclusion}

The abstract and visual nature of learning geographical concepts makes it necessary to integrate information technologies to facilitate learning. The important parts of geography in secondary education (physical, regional, and practical geography) consist of abstract knowledge. Therefore, it is crucial for teachers to use appropriate information technologies to convey geographical information to students. Reinforcing the relevant equipment, proper training, and accessibility of information technology can solve these problems. The policy makers should be aware of the role information technologies play in building students' understanding of geographical concepts. In this study, it was pointed out that the most important challenges were accessibility, inadequate materials, and poor training from teacher training institutions.

There are limited scholarly articles directly related to senior high school teachers' attitudes about ICT in the Ghana education system and this could have undermined the prediction and interpretation of the findings. This study was limited to one metropolitan area in Ghana, and the results could be different if other metropolitan schools were added to the study. Finally, the participants' honesty and their variances in the interpretation and understanding of the questions could have played a vital role this study. The questionnaire drew responses that represented teacher perceptions. This may have been swayed by other variables not mentioned in this study. 


\section{References}

Acquah, P. C., Asamoah J. N., \&. Konadu, D. D. (2017). Introduction of geographical information systems (GIS) in technical university education in Ghana: Challenges and the way forward. Review of International Geographical Education Online, 7(2), 207-220.

Agyei, D. D. (2014). Analysis of Technology Integration in Teacher Education in Ghana. Journal of Global Initiatives: Policy, Pedagogy, Perspective. 8, (1), 69-86

Agyei, D. D., \& Voogt, J. (2011). ICT use in the teaching of mathematics: Implications for professional development of pre-service teachers in Ghana. Education and Information Technologies, 16(4), 423-439

Agyeman, D. K., Baku, J. J. K., Gbadamosi, R., Addabor, E., Adoo-Adeku, K., Cudjoe. M., Essuman, A. A. (2000). Review of Education Sector Analysis in Ghana 19871998. France: UNESCO.

Ali, G., Haolader, F., \& Muhammad, K. (2013). The Role of ICT to Make TeachingLearning Effective in Higher Institutions of Learning in Uganda. International Journal of Innovative Research in Science, Engineering and Technology, 2(8), 4061-4073.

Amenyo, J. T. (2003). A model of national ICT policy for a sustainable development of Ghana: A system-theoretic approach based on SOCAR analytics, p. 5

Amossun, P. A. (2016). Why Nigerian geography teachers scarcely and scantly teach map reading and why students are scared of it. African Educational Research Journal, 4(2), 42-48.

Audet, R. H., \& Paris, J. (1997). GIS implementation model for schools: Assessing the critical concerns. Journal of Geography, 96, 284-300.

Baker, T. R. (2015). WebGIS in education. In O. Muniz-Solari, A. Demirci, \& J. van der Schee (Eds.), Geospatial technologies and geography education in a changing world: Geospatial practices and lessons learned (pp. 105-115). Tokyo, Japan: Springer.

Bednarz, S. W. (2004) Geographic information systems: A tool to support geography and environmental education? GeoJournal, 60(2), 191-199.

Brooker, S., \& Michael, E. (2000). The potential of geographical information systems and remote sensing in the epidemiology and control of human helminth infections. Adv. Parasitol, 47, 245- 288.

Brownell, K. (1997). Technology in teacher education: Where are we and where do we go from here? Journal of Technology and Teacher Education 5, 117-138. 
Buabeng-Andoh, C. (2012). Factors influencing teachers' adoption and integration of information and communication technology into teaching: A review of the literature. International Journal of Education and Development Using Information and Communication Technology, 8, 136-155

Buabeng-Andoh, C., \& Yidana I. (2015). Teachers' ICT usage in second-cycle institutions in Ghana: A qualitative study. International Journal of Education and Development using Information and Communication Technology (IJEDICT, 11(2), 104-11

Cheung, A. C., \& Slavin, R. E. (2013, June 13). The effectiveness of educational technology applications for enhancing mathematics achievement in K-12 classrooms: A meta-analysis. The best evidence encyclopedia (ERE). Johns Hopkins University School of Education's Center for Data-Driven Reform in Education (CDDRE). Retrieved from https://files.eric.ed.gov/fulltext/ED527573. pdf

Cova, T. J. (1999). GIS in emergency management. Geographical information systems, 2, 845-858.

CRDD-Curriculum Research and Development Division (2007). Teaching Syllabus for Information and Communications Technology (Core): Senior High School. Accra, Ghana: Ministry of Education Science and Sports.

Dankwa, W. A. (1997, May 27). SchoolNet: A catalyst for transforming education in Ghana. Retrieved from https://www.isoc.org/inet96/proceedings/c6/c6_1.htm

Davidsen, J., \& Christiansen, E. (2014). Mind the hand: A study on children's embodied and multimodal collaborative learning around touchscreens. Designs for Learning, 6, 10-33.

Davidsen, J., \& Georgsen, M. (2010). ICT as a tool for collaboration in the classroom challenges and lessons learned. Design for Learning, 3(1-2), 54-69.

Doering, A., Koseoglu, S., Scharber, C., Henrickson, J., \& Lanegran, D. (2014). Technology integration in $\mathrm{K}-12$ geography education using TPACK as a conceptual model. Journal of Geography, 113(6), 223-237.

Dooley, K. E. (1999). Towards a holistic model for the diffusion of educational technologies: An integrative review of educational innovation studies. Educational Technology \& Society, 2(4), 125-138.

Earle, R. S. (2002). The integration of instructional technology into public education: Promises and challenges. Educational Technology Magazine, 42(1), 5-13. 
Folson, R. B. (1995). The contribution of formal education to economic development and economic underdevelopment Ghana as a paradigm (Vol. 619). Frankfurt: Peter Lang Inc.

Fry, C. (1999). GIS in Telecommunications. In P. Longley, M. Goodchild, D. Maguire, \& D. Rhind, eds., Geographical Information Systems Volume 2: Management, New York: John Wiley and Sons.

Gall, M. D., Gall, J. P., \& Borg, W. R. (2003). Educational Research: An introduction (7 $7^{\text {th }}$ Ed.) New York: Pearson Education Inc.

Ghana Statistical Service (2014, June 13). 2010 population and housing census. Retrieved from http://www.statsghana.gov.gh/docfiles/2010_District_Report/ Ashanti/KMA.pdf

Goktas, Y., Yildirim, S., \& Yildirim, Z. (2009). Main barriers and possible enablers of ICTs integration into pre-service teacher education programs. Educational Technology \& Society, 12(1), 193-204.

Government of Ghana. (2002). Introducing information and communications technology in pre-tertiary institutions: A policy framework. Accra: Government publishers.

Hawkins, R. (2002) Ten Lessons for ICT and Education in the Developing World. The global Information Technology Report 2001-2002.

Hennessy, S., Harrison, D., \& Wamakote, L. (2010). Teacher factors influencing classroom use of ICT in sub-Saharan Africa. Itupale Online Journal of African Studies (Education in Africa: Developments in the 21st Century), 2, 39-54.

Hikkarainen, K., Ilomaki, L., Lipponen, L., Muukkonen, H., \& Rahikainen, M. (2000). Students skills and practices of using ICT: Results of a national assessment in Finland. Computers and Education, 34(2), 103-117.

Inkoom, D. K. (2009). Planning education in Ghana. Unpublished case study prepared for the Global Report on Human Settlements.

Jarvis, C.H., Kraftl, P., Dickie, J. (2017). Connecting spatial literacy with children's geographies: GPS, Google Earth and children's everyday lives. Geoforum 81, 22-31. https://doi.org/10.1016/j.geoforum.2017.02.006.

Jo, I. (2016). Future teachers' dispositions toward teaching with geospatial technologies. Contemporary Issues in Technology \& Teacher Education, 16(3), 310-327.

Kerski, J. J. (2001). A national assessment of GIS in American high schools. International Research in Geographic and Environmental Education, 10, 72-84. 
Kihoza, P., Zlotnikova, I., Bada, J., \& Kalegele, K. (2016). Classroom ICT integration in Tanzania: Opportunities and challenges from the perspectives of TPACK and SAMR models. International Journal of Education and Development using Information and Communication Technology (IJEDICT), 12(1), 107-128

Lai, C. (2015). Modelling teachers' influence on learners' self-directed use of technology for language learning outside the classroom". Computers \& Education, 82(3), 74-83.

Lai, G., Zhu, Z., \& Williams, D. (2017). Enhance students' learning in business statistics class using video tutorials. Journal of Teaching and Learning with Technology, 6(1), 31-44. https://doi.org/10.14434/jotlt.v6.n1.21161

MaKinster, J., \& Trautmann, N. (2014). The nature of teacher knowledge necessary for the effective use of geospatial technologies to teach science. In J. MaKinster, N. Trautmann, \& M. Barnett (Eds.), Teaching science and investigating environmental issues with geospatial technology: Designing effective professional development for teachers (pp. 333-353). New York, NY: Springer.

Mangesi, K. (2007, May 16). ICT in education in Ghana. Retrieved from http://www. infodev.org/infodev-files/resource/InfodevDocuments_406.pdf

Martin, L. (2011). Teaching business statistics in a computer lab: Benefits or distraction? Journal of Education for Business, 86(6), 326-331.

Mereku, D. K., Yidana, I, Hordzi, W., Tete-Mensah, I., Tete-Mensah, W., \& Williams, J. B. (2009, April 17). Pan African Research Agenda on the Pedagogical Integration of ICTs: Ghana Report. Retrieved from http://www.ernwaca.org/panaf/pdf/phase-1/ Ghana-PanAf_Report.pdf

Mfum-Mensah, O. (2003). Computers in Ghanaian Secondary Schools: Where does equality come in? Current Issues in Comparative Education, 6(1), 40-49.

Mikre, F. (2011). The roles of information communication technologies in education. Review article with emphasis on the computer and Internet. Ethiopian Journal of Education \& Science, 6(2), 109-126.

Ministry of Education (2015, June 10). Ashanti region. Retrieved from http:// ghanaschoolsinfo.org/ScoolMappingDigest/ASHANTI_REGION.pdf

Mumtaz, S. (2000). Factors affecting teachers' use of information and communications technology: A review of the literature. Journal of Information Technology for Teacher Education, 9(3), 319-342.

Munienge M., Jones T. and Muhandji K. (2013). Integration of ICT in education: Key challenges. International Journal of Emerging Technology and Advanced Engineering 3(11), 515-520. 
Murayama, Y., \& Thapa, R. B. (2008, April 8). Land evaluation for peri-urban agriculture using analytical hierarchical process and geographic information system techniques: A case study of Hanoi. Retrieved from https://www. researchgate.net/profile/Rajesh_Thapa2/publication/223500472_Land_ evaluation_for_peri-urban_agriculture_using_analytical_hierarchical_process_ and_geographic_information_system_techniques_A_case_study_of_Hanoi/ links/0deec536c6b2e6a6ee000000.pdf

Natia, J. A., \& Al-hassan, S. (2015). Promoting teaching and learning in Ghanaian Basic Schools through ICT. International Journal of Education and Development using Information and Communication Technology (IJEDICT), 11(2), 113-125.

National Geography Society (2016, November 20). Retrieved from http:// nationalgeographic.org/encyclopedia/geographic-information-system-gis/

Norrby M., Grebner C., Eriksson J., Bostrom J. (2015). Molecular rift: Virtual reality for drug designers. J Chem Infrom Model, 55, 2475-2482.

Patel, P., \& Patel, N. (2017). ICT pedagogy for effective learning, education and quality evaluation. International Journal of Computer \& Mathematical Sciences. 6(5), 101-107.

Patterson, M. W., Reeve, K., \& Page, D. (2003) Integrating Geographic Information System into secondary curricula. Journal of Geography, 102(6), 275-281.

Quist, H. O. (2003). Secondary education - a 'tool' for national development in Ghana. A critical appraisal of the post-colonial context. Africa Development, 28(3\&4), 186-210.

Rastogi, A., \& Malhotra, S. (2013). ICT skills and attitude as determinants of ICT pedagogy integration. European Academic Research, 1(3), 301-813.

Roschelle, J., Shechtman, N., Tatar, D., Hegedus, S., Hopkins, B., Empson, S., ......... Gallagher L. P. (2010). Integration of technology, curriculum, and professional development for advancing middle school mathematics: Three large-scale studies. Am. Edu. Res. J. 47, 833-878.

Sawyer, C.F, Butler, D. R, \& Curtis, M. (2010). Using webcams to show change and movement in the physical environment. Journal of Geography, 109(6), 251 - 263

Shabiralyani, G., Hassan, S. K., Hamad, N., \& Iqbal, N. (2015). Impact of visual aids in enhancing the learning process case research: Districk Dera Ghazi Khan. Journal of Education and Practice, 16(19), 226-234.

Shin, E. (2006). Using Geographic Information System (GIS) to improve fourth graders' geographic content knowledge and map skills. Journal of Geography, 105(3), 109-120. 
Smith, C. A., Moyer, C. A., \& Schugar, H. R. (2011). Helping teachers develop positive dispositions about technology-based learning: What a brief global learning project revealed. Journal of Educational Technology Development and Exchange, 4(1), 1-14.

Trelease, R. B. (2016). From chalkboard, slides, and paper to e-learning: How computing technologies have transformed anatomical sciences education. Anat Sci Educ, 9, 583-602.

Vedat, A. (2017). Landslide susceptibility analysis of adakli district (bingöl) by geographic information systems (gis). International Journal Of Eurasia Social Sciences 8(26), 150-175

Warner, L. L., \& Diab, R. D. (2012). Use of geographic information systems in an environmental impact assessment of an overhead power line. Impact Assessment and Project Appraisal, 20(10), 39-47.

Wei, W. (2012). Research on the Application of Geographic Information System in Tourism Management. Procedia Environmental Sciences, 12, 1104-1109.

Zeigler, D. J. (2007). Teaching Geography in an Interconnected World. Independent School, 66(3), 94-97.

Zhang, J. (2007). A cultural look at information and communication technologies in Eastern education. Educational Technology Research and Development, 55, 301-315. 